\title{
A proposal on teaching methodology: cooperative learning by peer tutoring based on the case method
}

Antonio Pozo, Juan Durbán, Carlos Salas, M. del Mar Lázaro

Antonio M. Pozo, Juan José Durbán, Carlos Salas, M. del Mar Lázaro, "A proposal on teaching methodology: cooperative learning by peer tutoring based on the case method," Proc. SPIE 9289, 12th Education and Training in Optics and Photonics Conference, 928912 (17 July 2014); doi: $10.1117 / 12.2070763$

Event: 12th Education and Training in Optics and Photonics Conference, 2013, Porto, Portugal 


\title{
A proposal on teaching methodology: cooperative learning by peer tutoring based on the case method
}

\author{
Antonio M. Pozo*, Juan José Durbán, Carlos Salas, Mª del Mar Lázaro \\ Departamento de Óptica, Facultad de Ciencias, Universidad de Granada, Granada 18071, Spain
}

\begin{abstract}
The European Higher Education Area (EHEA) proposes substantial changes in the teaching-learning model, moving from a model based mainly on the activity of teachers to a model in which the true protagonist is the student. This new framework requires that students develop new abilities and acquire specific skills. This also implies that the teacher should incorporate new methodologies in class. In this work, we present a proposal on teaching methodology based on cooperative learning and peer tutoring by case study. A noteworthy aspect of the case-study method is that it presents situations that can occur in real life. Therefore, students can acquire certain skills that will be useful in their future professional practice. An innovative aspect in the teaching methodology that we propose is to form work groups consisting of students from different levels in the same major. In our case, the teaching of four subjects would be involved: one subject of the 4th year, one subject of the 3rd year, and two subjects of the 2nd year of the Degree in Optics and Optometry of the University of Granada, Spain. Each work group would consist of a professor and a student of the 4th year, a professor and a student of the 3rd year, and two professors and two students of the 2 nd year. Each work group would have a tutoring process from each professor for the corresponding student, and a 4th-year student providing peer tutoring for the students of the 2nd and 3rd year.
\end{abstract}

Keywords: Cooperative learning, tutoring, peer tutoring, case-study methodology.

\section{INTRODUCTION}

The European Higher Education Area (EHEA) proposes substantial changes in the teaching-learning model, moving from a model based mainly on the activity of teachers to a model in which the true protagonist is the student. ${ }^{1-3}$ This new framework requires that students develop new abilities and acquire specific skills. This also implies that the teacher should incorporate new methodologies in class.

One way to encourage student involvement in the teaching-learning process is by incorporating active methodologies. ${ }^{2,4}$ In the present work, we propose an active methodology based on the case-study method and on cooperative learning, ${ }^{5-9}$ with teacher-student tutoring and peer tutoring among students, ${ }^{10}$ in which different subjects and different academic levels would be involved in the same degree. In our specific case, these would be the 2nd, 3rd, and 4th year of the Bachelor's Degree in Optics and Optometry at the University of Granada (Spain). For this, our intent is to develop the project once the Bachelor's Degree has been completely implemented, as the work groups would be composed of students in the 2nd, 3rd, and 4th years. It is important to note that, although we would carry this out for the Bachelor's Degree in Optics and Optometry, the teaching methodology presented could be applied to other degrees.

In learning based on the case studies, the aim is to put into practice alternatives to manage problems and to make decisions as the result of information which enables responses that are plausible and effective with respect to the contexts studied. ${ }^{11-14}$ This method includes a brief history on the development of the situation, the presentation of the case to be resolved, and the application of the theory of the subject on the part of the student or group of students seeking to resolve the case. A noteworthy aspect of this method is that it enables the proposal of situations that resemble real life or even are situations that can arise in real life, so that the student acquires certain skills that will be useful in a future profession. Other notable characteristics of this methodology are that: it bridges the gap between theory and practice; the students develop competence in analysis, synthesis, and decision; it permits the study of different alternatives; the students resolve problems in a joint way; and the students share academic knowledge, prior experience, and even personal values.

*ampmolin@ugr.es; phone (34) 958241902; fax (34) 958248533

12th Education and Training in Optics and Photonics Conference, edited by

Manuel F. P. C. Martins Costa, Mourad Zghal, Proc. of SPIE Vol. 9289, 928912

(c) 2014 SPIE, OSA, IEEE, ICO · doi: 10.1117/12.2070763

Proc. of SPIE Vol. 9289 928912-1 
In the teaching method presented here, we propose the study of cases for groups of students rather than for individuals, seeking to stimulate cooperative learning, based on the following characteristics: ${ }^{15}$

- Positive interdependence: each student in the group should be aware that the individual's work is important, as it determines the success of each student as well as of the group.

- Face-to-face interaction: group work encourages direct interaction among the students, sharing resources, helping and reinforcing one another's efforts.

- Individual responsibility: each student is co-responsible for the success of the group.

- Abilities inherent in small groups: the student should acquire, develop, and employ basic abilities of working in a group.

- Evaluation of the results and of the process: the group should carry out activities of reflection and appraisal of the work in the group.

As mentioned above, this project involves four subjects of the Bachelor's Degree in Optics and Optometry of the University of Granada. These subjects are: Visual Rehabilitation (4th year), Optometry IV (3rd year), Optometry II (2nd year), and Technology of Ophthalmic Lenses I (2nd year). The teaching of these subjects is based on lecture, problem solving in class, and practice sessions. Sometimes the lecture classes may lead to a passive attitude on the part of the student. With respect to problem solving in the class and the practice sessions, despite being important to exercise and apply what is learned in the theory class, the acquisition of certain skills and abilities that are professionally important is limited.

One innovative aspect in the teaching methodology that we propose is that the work groups would be formed by students of the four subjects covered. The teaching staff would propose cases in such a way that to resolve them the student would need knowledge of each of the four subjects.

\section{OBJECTIVES}

Groups of cooperative learning will be formed with tutoring by a professor and peer tutoring by students of the upper levels to students of the lower levels. The groups composed of students of the $2 \mathrm{nd}$, 3rd, and 4th years will have to resolve a real-life (or simulated) case that will require knowledge from the four subjects involved in the project. Afterwards, the resulting work will be presented in class.

The objectives of the project are:

On the one hand, the execution of the project will teach the student to:

- Put into practice the knowledge acquired in the lecture classes.

- To resolve problems in a shared way.

- To make decisions.

- To direct efforts.

- To create a climate of trust.

- To communicate with peers.

- To resolve conflicts.

- To promote the success of the other members of the group.

- To help, support, to encourage, and congratulate other group members.

- To develop competence in problem analysis and synthesis and in decision making when faced with different alternatives. 
Also, the participants will strengthen aspects such as:

- Dialogue.

- Writing.

- The search for information from diverse sources (books, journals, etc.).

Finally the execution of the project will enable students:

- To gain an interdisciplinary vision, relating knowledge from disparate material, since, to resolve the cases proposed, the student will need to apply theories from the four subjects included in the project.

- To complement and put into practice the training received through the conventional methods.

- Familiarize themselves with working in a group.

- Develop planning and organizational skills.

\section{TEACHING METHODOLOGY}

The present project will be voluntary for the students. The students that participate in this project will have extra credit in the final grading of the subject, considering that the students were sufficiently motivated to participate in the activities proposed.

As commented in Section 2, the idea is to have cooperative learning groups based on the study cases. Each work group will be formed by 4 professors and 4 students, i.e. one professor and one student in the subjects: Visual Rehabilitation (4th year), Optometry IV (3rd year), Optometry II (2nd year), and Technology of Ophthalmic Lenses I (2nd year). In each group, there will be tutoring by the professor for the student of the corresponding year as well as peer tutoring by students in the upper levels helping students in the lower levels.

The professor of the subject of the 4th year, with the collaboration of the other three professors involved, will prepare cases that include a real-life (or simulated) case history and that will require the professional intervention of an Optometrist. In this way, the students are offered the opportunity to analyse situations and to make decisions based on their knowledge of the subjects studied so far in order to undertake professional measures.

At the beginning of the semester, the professor of the 4th year presents the activity and explains the cases in class; students from the 4th year are asked to volunteer and cases are assigned by drawing lots among the volunteers. Similarly, the activity is presented and the cases are explained to the 3rd-year class, and the same number of volunteers are requested as in the 4th year. Finally, the same process is followed in the two subjects of the 2 nd year, asking for 2 volunteers for each one from the 4th year. Next, groups are formed at random by lots.

After the composition of the groups is known, the professor of the 4th year meets with all the groups to explain the working method and the evaluation system. From this time on, the students begin to work and plan their meetings as a group.

The students from the 4th year should be capable of focussing on and resolving the case proposed, as they would have studied three of the subjects included in the project and would be studying the fourth during this project. The students of the 3 rd year could gain an overall idea of the case proposed, but they would lack the knowledge provided in the 4th year. For students in the 2nd year, it would be more difficult to see the possible overall solution of the case proposed, as they would have studied only the first two subjects included in the case proposed. Therefore, the groups are made up of mixed members, as these students not only are not classmates but they also belong to different levels of studying. This is intended to encourage the acquisition of skills in cooperation and social interaction.

The 4th-year student acts as the coordinator of the case proposed and of the group, having more knowledge and a broader vision of the case proposed, in addition to being normally older and having more experience. The 3rd-year student is responsible for coordinating and directing students of the 2nd year and, cooperating all together, they try to find the best solution for the case proposed. In this way, the students learn from one other. The 4th- and 3rd-year students learn to coordinate a work group and they refresh their memories concerning what they studied in the lower levels. The 
2nd-year students gain a broader vision of the direction of their current studies with respect to their future studies and ultimately their profession.

Once the work group meets and studies the case proposed, the students work to establish a hypothesis, requiring students from the 3rd and 4th years to renew their prior knowledge. Finally, each work group prepares a work plan with its corresponding distribution of tasks. Each of the 4 students making up each group must undertake personal work of searching for information in such a way that the students are responsible for their own learning and are co-responsible for the learning of their classmates. In the ensuing meetings of each group, contributions from all the group members are brought together (information found, ideas formulated, reflections made, etc.), thereby motivating the discussion of ideas, concepts, and methods in order to prepare the final resolution of the case proposed. This will favour positive interdependence, as each member is responsible for the success of the group and should be aware that individual success depends on the success of the others. During the working relations, there will also be face-to-face interaction among the four students, enabling the flow of knowledge, especially from the upper levels to the lower one (from 4th- and 3rd-year students to 2nd-year students), and a review of knowledge especially from the lower level to the upper ones (from 2ndyear students to 4th- and 3rd-year students). Furthermore, each group member bears individual responsibility of being co-responsible for the success and achievements of the group, assuming the conclusions and procedures established by consensus. In this way, the students develop basic skills of working in a group and of evaluating the results of the process.

In the meetings held by each group, the students will be directed and coordinated only by the professor of the 4th year, who will evaluate the overall work. The professor of the 3rd year will evaluate the work taking into account the subjects of the 3rd and 2nd years, while the professors of the 2nd year will evaluate the work considering only their respective subject matter. In this way, the 4th-year students must guarantee that the case is well resolved in all its aspects, the 3 rdyear students in aspects other than those of the 4th year, and the 2nd-year students only issues related to their subject, with no negative repercussions if the higher-level students fail to develop their part adequately.

Finally, the corresponding student of each group will explain the resolution of the case in the classroom where the subject is taught. In addition, the 2nd-year students will summarize the part corresponding to the 3rd and 4th year of studies, and the 3rd-year student will summarize the part corresponding to the 4th-year student. In this way, the 2nd-year students will gain a broader perspective concerning the way in which the basic subject matter under study can be useful in solving cases very close to real situations that arise in professional contexts.

With respect to the tutoring, the professor who teaches the 4th year supervises the work of the 4th-year student and therefore indirectly the entire group. In the first meeting, this student presents an outline of the case and its possible solutions. In subsequent meetings, the 4th-year student presents the progress made with the group work and, after a previously established amount of time, presents the final report with the solution of the case. The professors of the 3 rd and 2nd year answer specific questions asked by the students, corresponding to the specific part of the case related to each professor's subject.

The professor of the 4th year, in collaboration with the professors from the 3rd and 2nd years, will take charge of:

- Preparing the case.

- Controlling the composition of the work groups and monitoring them.

- Suggesting evaluation criteria and appraising the tasks executed.

- Helping 4th-year students to be a model in the group in terms of conduct and attitude (verbal, gestural, etc.)

- Helping the 4th-year student to stimulate idea exchanges and decision justification, to evaluate the work performed, and to resolve problematic situations (a domineering student, a student who does not want to work in a group, a marginalized student, etc.).

The 4th-year student is in charge of:

- Organizing and controlling the meetings of the group.

- Defining the tasks of each group member.

- Verifying that each member knows the aims of the work. 
The evaluation of the 4th-year student will be ongoing and final: "ongoing" in the sense of informing the 4th-year professor on the progress of the group and on the work finished; and "final" in the sense that at the resolution of the case the professor will evaluate the results.

The evaluation of the 3rd- and 2nd-year students will be "final" depending on the work presented.

The scheme shown in Figure 1 summarizes the interactions between the participants of the project, according to the description presented above.

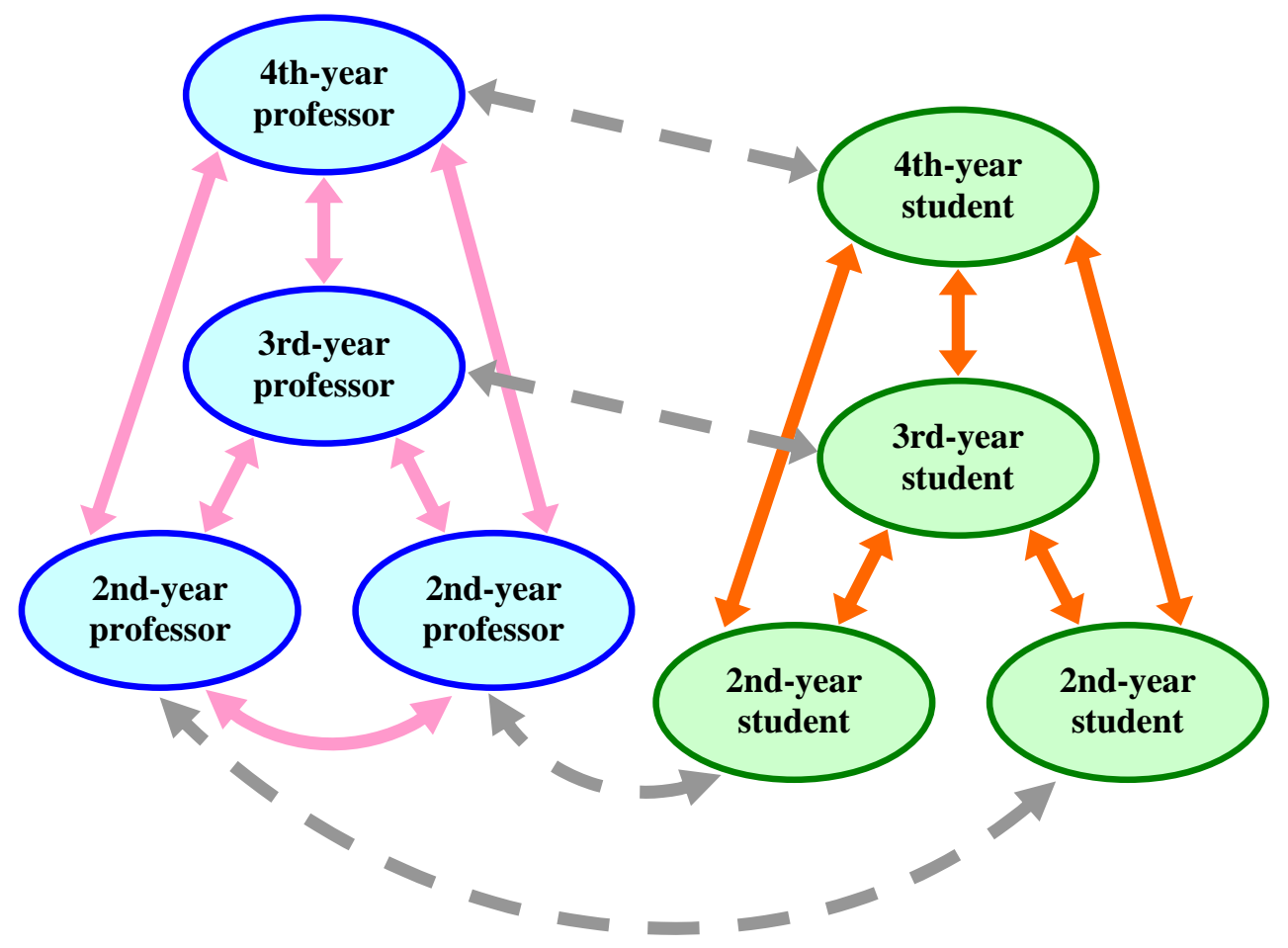

Figure 1. Interactions among the members of each work group during the execution of the project (professors and 2nd3rd- and 4th-year students).

The resolution of the case will be evaluated in the following way:

The grade earned by the 4th-year student will be the average between the grade earned individually (continuous and final) and the average of the grades of the other three members of the group. In this way, the 4th-year student will take responsibility for the work of the other group members.

The grade earned by the 3rd-year student will be the average between the grade earned individually and the average of the grades of the two 2nd-year students. In this way, the 3rd-year student will take responsibility for the work of the 2ndyear members of the group but not for the work carried out by the student of the 4th year. Finally, the grade earned by the students of the 2 nd year will be the average of their individual grade. Thus, the 2nd-year students do not become responsible for the work done by their fellow group members of the higher levels. 


\section{TIMETABLE}

This project could be executed according to the following plan (Table 1).

- 1st week: class activity is presented ( $2 \mathrm{nd}$, $3 \mathrm{rd}$, and 4 th year).

- 2nd week: the professors responsible for each subject ask for volunteer students to participate in the project.

- 3rd week: the work groups composed of students from the three levels are formed.

- 4th to 13th week: the different parts of the work are executed in each of the groups formed.

- 14th and 15th weeks: the final works are presented in each class.

Table 1. Timetable of activities.

\begin{tabular}{|c|c|c|c|c|c|}
\hline 1st semester & $\begin{array}{l}\text { Presentation } \\
\text { of the } \\
\text { activities }\end{array}$ & $\begin{array}{l}\text { Request for } \\
\text { volunteers }\end{array}$ & $\begin{array}{l}\text { Formation of } \\
\text { groups }\end{array}$ & $\begin{array}{l}\text { Execution } \\
\text { of work }\end{array}$ & $\begin{array}{l}\text { Presentation } \\
\text { of the work }\end{array}$ \\
\hline 1st week & $\mathrm{X}$ & & & & \\
\hline 2nd week & & $\mathrm{X}$ & & & \\
\hline 3rd week & & & $\mathrm{X}$ & & \\
\hline 4th week & & & & $\mathrm{X}$ & \\
\hline 5th week & & & & $\mathrm{X}$ & \\
\hline 6th week & & & & $\mathrm{X}$ & \\
\hline 7th week & & & & $\mathrm{X}$ & \\
\hline 8th week & & & & $X$ & \\
\hline 9th week & & & & $X$ & \\
\hline 10th week & & & & $\mathrm{X}$ & \\
\hline 11th week & & & & $X$ & \\
\hline 12th week & & & & $\mathrm{X}$ & \\
\hline 13th week & & & & $X$ & \\
\hline 14th week & & & & & $X$ \\
\hline 15th week & & & & & $X$ \\
\hline
\end{tabular}

\section{CONCLUSIONS}

In this work, we propose a methodology for active teaching, based on the cooperative learning and peer tutoring by case studies.

The learning by students in an active way generates more interest on their part, more overall effectiveness in fulfilling the objectives and the acquisition of transversal competence that they might otherwise not reach.

Specifically, learning based on case studies encourages students to develop competence in analysis, synthesis, and decision making, enabling them to contemplate different alternatives, to solve problems in a shared as well as individual way, and to contribute academic knowledge, prior experience, and even personal values in such a way that students learn from one another. 
With the method proposed, the aim is to stimulate cooperative learning which encompasses positive interdependence, face-to-face interaction, individual responsibility, basic skills of working in a group, and the development of activities of reflection and evaluation. In addition, the students in each work group, on coming from different academic years, not only are not classmates but also are of different levels. This promotes better acquisition of competence in cooperation and social interaction.

What we consider the most novel feature of this project is to introduce the peer tutoring by students from the upper levels to help students of the lowest level, a very uncommon approach in the Spanish educational system. With this initiative, the aim is not only to encourage all the benefits derived from cooperative work, but also to permit the exchange of knowledge and of experiences between students.

In our case, the work groups will be formed by students of four different subjects of the Bachelor's Degree in Optics and Optometry of the University of Granada (Spain). These subjects are: Visual Rehabilitation (4th year), Optometry IV (3rd year), Optometry II (2nd year), and Technology of Ophthalmic Lenses I (2nd year). However, the methodology proposed could be adapted to be implemented for other degrees.

\section{ACKNOWLEDGEMENTS}

The authors express their appreciation to David Nesbitt for translating the text into English.

\section{REFERENCES}

[1] Benito, A. and Cruz, A., "Nuevas claves para la docencia universitaria en el Espacio Europeo de Educación Superior," Narcea, Madrid (2005).

[2] Ubieto, I. (coord.), Domingo, M., García, F. J. and Paulo, A., "Practicar con la teoría: metodologías activas en información y documentación en el marco del Espacio Europeo de Educación Superior,” Prensas Universitarias de Zaragoza, Zaragoza (2008).

[3] Universidad Rey Juan Carlos, "Calidad e innovación docente en el marco de la Convergencia Europea," Consejo Social. Vicerrectorado de Profesorado, Titulaciones, Ordenación Académica, Coordinación y Campus, Madrid (2008).

[4] López, F., "Metodología participativa en la enseñanza universitaria,” Narcea, Madrid (2005).

[5] Ferreiro, R., "Estrategias didácticas del aprendizaje cooperativo: el constructivismo social, una nueva forma de enseñar y aprender," Trillas, México (2006).

[6] Ferreiro, R. and Calderón, M., "El ABC del aprendizaje cooperativo. Trabajo en equipo para enseñar y aprender," Trillas, México (2006).

[7] Gavilán, P. and Alario, R., "Aprendizaje cooperativo: una metodología con futuro: principios y aplicaciones," CCS, Madrid (2010).

[8] Joos, A. and Veerle Ernalsteen, V. (edits.), "CLIEC: A report on the methodology of cooperative learning and its implementation in different European educational settings," Gent, Universiteit Gent (2005).

[9] Prieto Navarro, L., "El aprendizaje cooperativo," PPC, Madrid (2007).

[10] Mullen, C.A (ed.), "The handbook of formal mentoring in higher education: A Case Study Approach," Christopher-Gordon Publishers, Inc; Norwood, MA (2008).

[11] Barnes, L. B., Christensen, C. R. and Jansen, A. J., "Teaching and the Case Method: Text, Cases, and Readings," Harvard Business School Press, Boston (1987).

[12] Herreid, C. F., "Case studies in science: a novel method of science education," Journal of College Science Teaching 23 (4), 221-229 (1994).

[13] Nilson, L. B., "Teaching at its best,” Jossey-Bass, San Francisco (2010).

[14] Pagès, T., Cornet, A. and Pardo, J. (coords.), "Buenas prácticas docentes en la universidad: Modelos y experiencias en la Universidad de Barcelona," Octaedro, Barcelona (2010).

[15] De Miguel, M. (coord.), "Metodologías de enseñanza y aprendizaje para el desarrollo de competencias. Orientaciones para el profesorado universitario ante el Espacio Europeo de Educación Superior," Alianza Editorial, Madrid (2006). 